\title{
Carus' Soul: From Metaphysical To Biological Unconscious
}

\author{
Aleš Vrbata \\ Universidade Estadual de Feira de Santana, Bahia, Brazil
}

\author{
VRBATA, A.: Carus' Soul: From Metaphysical to Biological \\ Unconscious. \\ Philosophica Critica, vol. 3, 2017, no. 1, ISSN 1339-8970, pp. 29-57.
}

The paper deals with the notion of the soul or psyche in German physician and thinker Carl Gustav Carus (1789-1869), his place in $19^{\text {th }}$ century German thinking of unconscious, his reception in C. G. Jung (or in E. Neumann) and contemporary post-Jungians (J. Hillman, W. Giegerich) and in contemporary philosophy (A. Nicholls, M. Liebscher, M. Bell). Even though today it is Jung who is considered a "scandalous" revivalist of "soul", i.e. Psychologie mit Seele in the western scientific discourse, this thesis is not totally true. In fact, Jung constituted continuity with older - pre-Freudian - authors who conceptualized the notion of unconscious (and "soul" with it) long before the old term Soul/die Seele was used by Jung. Carus' notion, however, does not constitute a rediscovered soul as it was conceived by medieval theology because it is conceived as biological, i.e. mainly unconscious with its own inherent evolutionary programming.

Key words: Carus - Jung - Soul - Romanticism - Philosophy of Unconscious

\section{Introduction}

A soul problem started to be seen as a problem to be thought during the $19^{\text {th }}$ century and even then no particular scientific discipline considered "soul" as pertaining to its territory. Consequently, in the modern, industrialized, secularized and scientific society "soul" became a vague term, a residue of older metaphysical paradigms. In the $19^{\text {th }}$ century its presence became limited only to romantic literature, music and some fields of medicine (psychology, psychiatry) and later on, in times of social-Darwinist biologization of social sciences, in nationalist doctrines (soul, race, nation, blood were used synonymously as a metaphysical groun- 
ding of national identity). Thus since the $19^{\text {th }}$ century "soul" has been a freefloating, not anchored term, which was used, misused and abused in different contexts and to different aims.

This paper pretends to shed light on the notion of soul as it was slowly reemerging from oblivion through the mediation of late romantic physician Carl Gustav Carus whose concept was not only surprisingly insightful but also ahead of his time. In many regards Carus constitutes the bridge between old metaphysical concepts of soul and modern psychophilosophical concepts, a bridge that contributed significantly to later Jung's or Neumann's conceptualizations. Even though there was no systematic "thinking of unconscious" in Carus' times and thus he could not work with already formulated concept of "unconscious", his concept of soul is a concept where the conscious level of life emerges from much deeper and supposedly unknowable unconscious, from totally impersonal dimension where, according to Carus, the organic nature (matter) meets or is mirrored in what was later called "primordial images" (Freud, Jung, Neumann, etc.). As Murray Stein puts it, "the world of spirit is distinguished from the world of nature by the factor of consciousness" (Stein 1989, 77) because in lower (unconscious) levels spirit and matter are united and intertwined.

Carus did not introduce the idea of historically layered collective unconscious as Jung did in his Psychology of Unconscious (Wandlungen und Symbole der Libido) but postulated a link between the spirit and the matter ("self-consciousness", human self-awareness emerges from "world-consciousness", i.e. unconscious identity with the world) and many of his terms remind us Freud's, Jung's or Neumann's terminology. Carus did not know so-called "recapitulation theory" ${ }^{1}$ but his view of the human psyche structure is a prototype of such a theory. According to many, Carus is still viewed as a scientist who "was perhaps the closest influence upon Jung's own formulations of the personal and the collective unconscious" (Hauke $2008,57)$. The aim of this article is to point at this direction: Carus as a significant predecessor of the idea of 1) consciousness-unconscious vital connection, 2) unconscious determines condition and evolution of consciousness, i.e. consciousness depends on the unconscious, 3) ontogeny recapitulates phylogeny, 4) archetype (primordial imagery) mirrors instinct. All these ideas were later developed not only by psychologists but also by biologists, their echo is found also in theologian Rudolf Otto's concepts of the sacred of the numinous, in volkisch Germanic nationalist scholars of religion like Jakob Wilhelm Hauer or in pioneering works of Jungian textual and literary critique (Maud Bodkin, Bettina L. Knapp).

${ }^{1}$ Recapitulation theory is also called biogenetic law or embryological parallelism, hypothesis introduced to biology by Ernst Haeckel ("ontogeny recapitulates phylogeny") and was extensively applied in depth-psychology and developmental psychology. 


\section{Modernity: Soul De-Ontologized}

In the archaic situation, the soul was that aspect of the human being that after death joined the ranks of the venerated, near-divine ancestors in the underworld. (...) Later (...) the soul was essentially what people's vital concern for "eternal salvation" and the fear of "eternal damnation" circled around. (...) But since in the modern world (...) the beyond and hereafter simply dropped out from the world conception and lost its credibility (....) modernity also had to lose the soul. The term became meaningless (...)

Giegerich $^{2}$

There are many ways how to approach soul phenomenon. This paper refers to history of psychology (Ellenberger, Giegerich), history of philosophy of unconscious (Nicholls-Liebscher, Giegerich), psychoterapy (Hillman, Giegerich) and the work of one of the most preeminent psyche theorist of the $19^{\text {th }}$ century Germany, Carl Gustav Carus (1789-1869), author of famous work Psyche: Zur Entwicklungsgeschichte der Seele. The term itself, "soul"/"die Seele", is not used today, especially in philosophy that prefers using more scientific sounding terms as "subject", "subjectivity" (Nicholls-Liebscher) or "thinking matter" (Bell 2010, 160). Situation in psychology seems no better. In spite of Carl Gustav Jung's attempts to rehabilitate the term "soul" (die Seele), translator of his Collected Works R. F. C. Hull $^{3}$ uses scientific sounding "psyche". In fact, similar situation is everywhere. According to Wolfgang Giegerich "academic psychology and most schools of psychotherapy do not use, or rather systematically avoid, the concept of soul. One talks instead, for example, about 'the psyche', about the 'behavior of the organism', or about 'what goes inside people' as 'the subjective aspect of human life', but not about the soul. The word soul is 'left to the poets' (and musicians: 'Soul') or in colloquial language survives as a façon de parler reserved for certain sentimental or romantic moments. From religion and theology, formerly the true home of the concept of soul, this word seems to have disappeared" (Giegerich 2012, 5).

Recapitulating evolution of "soul" in the West, Giegerich emphasizes - as a historical key turning point - an academic dispute between Friedrich Albert Lange's Psychologie ohne Seele (Geschichte des Materialismus, 1866) and Carl Gustav

2 (Giegerich 2012, 14-15).

3 Jung used both terms almost always interchangeably. More frequently Jung used the term "soul". 
Jung's Psychologie mit Seele. For Giegerich Jung's thesis is what he labels as "scandalous position" because "Lange's idea of a 'psychology without soul' was by no means far-fetched and arbitrary, not merely a possible thesis, not idiosyncratic choice, but a fully justified one. It simply corresponded to the state of affairs, to the best insight available. All Lange had done was to honestly and conscientiously draw the necessary consequences of the historical development of human knowledge concerning notion of soul" (Giegerich 2012, 7-8). Self-evidence of Lang's position was later - quite naturally - supplemented by Nietzsche's declaration of "death of God". For Giegerich both Lange and Nietzsche constitute significant mouthpieces of Weltanschauung of that time because they "did not merely present their personal and debatable views. They were rather [...] the mouthpiece of the objective psyche" (Giegerich 2012, 8).

Lange's and Nietzsche's position constitute a peak moment of the western modernity evolution because their demise of the soul and death of God had in fact started a long time before medieval soul was substituted by the modern concept of subjectivity: "As late as the Baroque age, the old concept of the soul as an immaterial substance that was the true core of the human person [...] had still remained undisputed [...]. But in contemporary philosophy, in the new thinking of Descartes, Spinoza and Hobbes, a shift away from the notion of soul had occurred, which helped to base man's self-understanding instead on the new notion of subjectivity" (Giegerich 2012, 8). Soul started transforming into a fossilized relic of the past already in the $18^{\text {th }}$ century, which is after all evidenced in the Georg Christoph Lichtenberg's statement: "One still says soul the way one says thaler, after the minted thalers have long disappeared" (Giegerich 2012, 10). Even though soul was becoming a subject or subjectivity and metaphysics of the soul started being substituted by theories of subjectivity or philosophy of mind, such a process was not very explicit. It is sentimentalism, Protestant movement of $18^{\text {th }}$ century Pietism or Schleiermacher's philosophy that lead Giegerich to the conviction that already in $18^{\text {th }}$ century soul was going through the process of "psychologization", i.e. became subjectivized, privatized, personalistic and ceased to be that immortal substance, causa sui as in Plato (to hayto kinoyn) (Giegerich 2012, 266) or Heraclitus ${ }^{4}$, whose being existence points beyond physical death. It was exactly in the $18^{\text {th }}$ century when "the sceptical, empiricist critique of the idea of the immortality of the soul increased" (Giegerich 2012, 268).

In other words, the source of the modern subjectivity has to do with the thought of the modern philosophy which does not envisage soul as a substance but as a subjectivity, intuition, "feeling" or "taste for infinite" as a basis for religion (Schleiermacher). Such a modern subjectivity can be noticed already in Descartes

4 "You would not find out the boundaries of soul, even by traveling along every path: so deep a logos does it have." 
who identifies soul with I: "En sorte que ce moi, c'est-à-dire l'âme par laquelle je suis que je suis, est entièrement distincte du corps ... "5. And after Descartes both John Locke and David Hume raised explicit doubts about the soul as substance.

How to explain then Jung's "scandalous" position? Of course, Giegerich is right when saying that soul was losing its metaphysical and ontological status already in the $18^{\text {th }}$ century and was becoming increasingly subjectivized, psychologized, privatized and personalized. In other words, modernity (17th century scientific revolution and $18^{\text {th }}$ century Enlightenment) led to de-objectification of soul.

But this trend was problematized long time before Freud and Jung. It was the movement of romantic philosophy, science and literature that constituted basic anti-thesis to the starting-points of mainstream Enlightenment philosophy and that offered a perspective which was reassumed by Jung. Jung and others (including young Freud), who contributed to the rehabilitation of soul referred to some $18^{\text {th }}$ century thinkers (Leibniz, Kant, Goethe).

\section{Unconscious Philosophically Conceptualized}

When speaking of Romanticism, one usually thinks of its expression in literature, in music, and in the arts; but in Germany, Romanticism also pervaded the fields of philosophy, science, and medicine. (...) nature cannot be understood in terms of mechanical and physical concepts only, but must be understood in terms of underlying spiritual laws, which the philosophy of nature endeavored to elucidate.

Ellenberger 6

Immersing into the issue of "soul problem" as rediscovered within the tradition of German romantic philosophy, today's philosophy localizes this concept within much larger context of - as Ellenberger puts it - The Discovery of the Unconscious. It was rather question of unconscious that became - approximately in the year 1800 - the central theme of German philosophy. In a sense, it was a consequence of what Giegerich calls Kantian "anthropological turning point". It was no sudden "breakthrough", but - as Arnim Regenbog observes - continuation of Problemgeschichte and Begriffgeschichte whose forerunners can be found already in Gautama Buddha (c. 563-483 BCE), Plato (423-347 BCE, theory of anamnesis), Plotinus (354-430 CE), St. Augustine (354-430 CE), Thomas Aquinas (1225-1274),

\footnotetext{
5 "The I, that is to say, the soul through which I am what I am."

${ }^{6}$ (Ellenberger 1970, 202).
} 
Meister Eckhart (1260-1328) or Jakob Böhme (1567-1624) (Regebogen-Brandes 1990, 647). Even though all these prominent thinkers did not explicitly conceptualize unconscious either phychologically, philosophically or biologically, their discourse intuited an unconscious dimension of human experience. As we will see further the very theme of unconscious was not the result of purely philosophical thoughts and was not limited to Germany, but appeared also in biology or physiology, both in Britain and France. This fact is noteworthy especially when taken into consideration in the case of Carl Gustav Carus' unconscious.

Modern philosophy did not conceptualize question of unconscious but rather applied itself to consciousness. In his Meditations on First Philosophy (1641) René Descartes posited dualism that became a central element of modern European thought. Here, res cogitans constituted a thinking substance, i.e. consciousness. Thus, human subject was identified with consciousness: "it could be that were I totally to cease from thinking, I should totally cease to exist" (Descartes 1996, 18). Having no concept of unconscious Cartesian philosophy reduced all psychic and mental to the field of consciousness. Situation is not so much different even though contemporary philosophy understood human subjectivity in various different ways (Nicholls-Liebscher 2010, 5). But this does not apply to some German heirs of Cartesian tradition of whom the most important is Gottfried Wilhelm Leibniz. In his Monadology (1714) Leibniz attempted to substitute Cartesian dualism by monism that would unify res extensa and res cogitans. According to Leibniz the world is constituted by extended and immaterial substances - monads which are capable of perceptions, are individual (unique), have their inner laws (programming) and each strives for what ot considers good. Monads have a spiritual quality: immaterial, individual, they are Godwards and reflect different aspects of God. Monads are "windowless", i.e. it is not possible to change them from outside and their development takes places in complete isolation. Even though monads develop independently of each other, their development follows what Leibniz terms l'harmonie pré-etablie.

Above mentioned theses from Leibniz's Monadology prove that human self, subject or soul received an ontological status. In contrast to Descartes Leibniz did not identify subject-subjectivity-soul with thinking. Leibniz speaks of mental process that take place under the threshold of consciousness. In his work Nouveaux essays sur l'entendement humain (finished in 1705 but published as late as 1765) Leibniz speaks of petites perceptions and perceptions insensibles as of those perceptions that take place without subject's full awareness. Here Leibniz clearly deviates from Descartes' supposition that substance of soul/subject lies in thinking. Monads/subjects receive perceptions of all entire universe - even during the sleep which means that there are also subliminal, i.e. darkened, unclear or not distinct perceptions. In this respect Leibniz sided with Locke's anti-Cartesian argumentation according to which essence of soul cannot consist in thinking. Locke was 
convinced that non-conscious states (sleep) can serve as a good proof that soul/subject is not exclusively a thinking subject. Thus Locke rejected that soul "should think, and not be conscious of it" (Locke 1997, 113).

Leibniz's supposition of unconscious perceptions cannot be considered conceptualization of unconscious but takes into account unconscious level of mental processes within the soul/subject. That is why he draws apart from "cogito ergo sum" and approximates to $18^{\text {th }}$ century forerunners (Wolff, Platner, Kant) of $19^{\text {th }}$ century unconscious concepts. According to Leibniz "there is in us an infinity of perceptions ... of which we are unaware because these impressions are either too minute and too numerous, or else too unvarying, so that they are not sufficiently distinctive on their own" (Leibniz 1996, 54-55). Perceptions that escape human consciousness Leibniz termed as petites perceptions, which - using today's parlance - sink below the threshold of consciousness into the unconscious. Next to them, there is what Leibniz terms apperceptions, i.e. perceptions of which one is reflexively aware. These ideas were later developed by Christian Wolff (16791764) and Ernst Platner (1744-1818). In his work Vernünftige Gedancken von Gott, der Welt und der Seele des Menchen, auch allen Dingen überhaupt (1720) Wolff defines con-sciousness on the basis of the capacity of differentiation. It is a self-reflexive knowledge, which enables us to perceive things as exterior (differrent from subject) and at the same time different from each other $(\S \S 728,729)$. On the contrary, to be unconscious would mean that the subject is not able to differrentiate "the difference between the things that attend us; then we are not conscious of the things that fall into our senses" (Wolff 1983, 455). But Wolff pays main attention to soul and moreover understands it in Cartesian way. Wolff equals unconscious with incapacity to differentiate things and phenomena in front of our senses. In this context Wolff uses expression "darkness of thoughts" (Dunkelheit der Gedancken) (Wolff 1983, 457).

Whereas philosophy and psychology of unconscious did not pay attention to the unconscious phenomenon (in a sense, the same can be said about Carus who mentioned unconscious only to explain conscious phenomena) in the long term, in the field of philosophical aesthetics idea of unconscious provoked attention already in the $18^{\text {th }}$ century only to return to philosophy in times of German classical philosophy and Romanticism. Already in 1759 Swiss mathematician Johann Georg Sulzer (1720-1779) declared that philosophers should pay particular attention to dark recesses of the soul, i.e. unconscious (die genauste Aufmerksamkeit auf die dunkeln Gegenden der Seele ... richten). For sure, such a suggestion was formulated in terms of rationalistic Enlightenment philosophy, i.e. as a suggestion of rationalistic analysis. However, Alexander Baumgarten (1714-1762) already in his time came up with the idea that the approach to unconscious requires other methods. Baumgarten even declared that the unconscious (perceptions 
obscurae) constitutes basis of the soul (fundus animae) ${ }^{15}$. But his innovative reception of Wolff is rather an exception.

Another but less innovative reception of Wolff is represented by Ernst Platner, who in his work Philosophische Aforismen (1776) used - probably for the first time in the history of philosophy - the term Unbewußten (unconscious). Platner finds himself within the Leibniz-Wolff tradition: soul (Seele) is a substance or power (Kraft) producing impressions and ideas (Wirkungen, Ideen) and is acitive all the time (also during the sleep, as indicated by Leibniz and Locke). According to Platner, soul produces both conscious (mit Bewußten) and unconscious material (dunkle Vorstellungen, ohne Bewußten). One can say, with certain exaggeration, that Platner anticipates Fechner who differentiates two aspects of the soul: conscious (diurnal) and - unconscious (nocturnal).

In Kant we find a first philosopher of Enlightenment whose name psychoanalysts repeatedly refer to as their forefather. According to Nicholls and Liebscher "Immanuel Kant arguably determined the way in which unconscious phenomena were understood in nineteenth-century German thought more than any other philosopher of the eighteenth century" (Nicholls-Liebscher 2010, 9). It is also today's archetypal/imaginal psychology that refers to Kant's concept of Einbildungskraft (process of imagining) as a fundamental turning point in the philosophical understanding of mental image (Kugler 2008, 84). In his influence Kant is by no means isolated. Kant of pre-critical period exhibits quite obviously Leibniz's influence when emphasizing his concept of petites perceptions in his work Versuch, den Begriff der negativen Grössen in die Weltweisheit einzuführen (Attempt to Introduce the Concept of Negative Magnitudes into Philosophy, 1763). Here, Kant ventures domain of psychology - as we have seen, undertaking quite common in the German philosophy of that time - and asks why a thought is suddenly substituted by another even without any conscious intention of the subject. Inspired by physics Kant believes that lesser power (intensity) is overpowerred by the greater power (intensity). Those mental contents that are clearer and more distinct are simply more powerful than those obscured (verdunkelt). Here we recognize Leibniz's influence, i.e. that of the concept of petites perceptions: "There is something imposing and, it seems to me, profoundly true in this thought of Leibniz: the soul embraces the universe only with its faculty of representation, though only an infinitesimally tiny part of these representation is clear" (Kant apud Nicholls-Liebscher 2010, 10).

In another work, Anthropologie in pragmatischer Hinsicht (Anthropology from a Pragmatic Point of View, 1798) Kant deals in detail with Leibniz's concept of petites perceptions as dunkle Vorstellungen. It seems that in the end of $18^{\text {th }}$ century

15 In the fourth edition (1759) of Metaphysica this latin expression is substituted by a German expression Grund der Seele. 
philosophical conceptualizations of human soul ceased to be exclusively philosophical and at the dawn of the $19^{\text {th }}$ century started to intertwine with the concepts of nascent Romantic psychology. It is noteworthy that this new generation of deutschsprächige thinkers frequently referred to Goethe. Carl Gustav Carus was one of those who owed to Goethe a considerable part of his ideas.

\section{Carus's Soul in Context}

Gleich dem durchaus Unbewußten wirken nämlich alle bereits früher einmal zum Bewußtsein gelangten, dann aber wieder unbewußt in der Seele schlummernden Gefühle und Erkentnisse immerfort auf das bewußte Seelenleben, wie auf das war wir das absolut unbewußte Seelenleben genannt haben, ein.

Carus, Psyche ${ }^{7}$

Preceding part of this paper I headlined Unconscious Philosophically Conceptualized because to get overall view on the concept of unconscious would mean necessary describe psychological conceptualization of the unconscious as well. In his monumenttal work The Discovery of the Unconscious (1970) Henri Ellenberger does not focus only on the notion of unconscious. Range of his scope is much wider and covers both history of psychology, culture, religion, philosophy and arts to conclude the book in a very erudite survey of Janet's, Freud's, Jung's and Adler's systems. However, the concept of unconscious extends through all his work and Ellenberger - similarly to Giegerich - believes that its birth has to do with the demise of Christian Weltanschauung within medicine and healing in Europe of that time. Whereas Giegerich describes such a passage pointing at the term "soul", Ellenberger describes the same passage describing two $18^{\text {th }}$ century healers: Johann Joseph Gassner (1727-1779) and Franz Anton Mesmer (1734-1815) as pointing at fundamentally different worldviews and thus symbolizing the divison line between two historical epochs. Whereas theoretical back-ground of Gassner was constituted by Christian myth and his main psychotherapeutic method was exorcism, theoretical background of Mesmer had a considerably modern charac-

7 Trans. "Like the unconscious proper, all feelings and experiences that have already attained consciousness, but then have unconsciously slept in the psyche, have an effect on the conscious psychic life, just as they affect what we have named the absolute unconscious" (Carus 1846, 76). 
ter. Mesmer explained his system in 1779 using 27 points ${ }^{8}$ and introduced his theory of animal magnetism which linked with contemporary physical theories ${ }^{9}$, i.e. integrated it into the Enlightenment scientific thinking ("Mesmer was seeking a 'rational' explanation and rejected any kind of mystical theory", Ellenberger 1970, 62). As Ellenberger aptly comments:

"Gassner, an immensely successful and popular healer, personified the forces of tradition. He had mastered an age-old technique that he applied in the name of the established religion, but the spirit of the times was against him. Mesmer, a son of the 'Enlightenment', had new ideas, new techniques, and great hopes for the future. He was instrumental in defeating Gassner and believed that the time was propitious for the onset of the scientific revolutionary that he had in mind" (Ellenberger 1970, 53).

Trajectories of Gassner's and Mesmer's careers did not have any link with contemporary philosophy, but rather psychotherapy. Moreover, at that time there was no psychological concept of unconscious. The same effect had a wave of spiritism whose beginning Ellenberger situates in 184710. It is noteworthy that when Mesmerian magnetism and hypnosis were in regress (1860-1880), new schools of psychotherapy (Nancy School, Salpêtrière) came into being and first preFreudian concepts of unconscious started being formulated.

Another approach - a bit more academic and turned to philosophy - is found in today's German philosopher Günter Göde. Conducting research into origins and transformations of the term "unconscious" Göde in his book Traditionslinien des "Unbewussten": Schopenhauer, Nietzsche, (Freud Tradition-Lines of the "Unconscious": Schopenhauer, Nietzsche, Freud) contextualized development of this concept till Sigmund Freud and concluded that in the background of Freud's metapsychological discourse there were three historico-philosophical traditions of un-

8 "(1) A subtle physical fluid fills the universe and forms a connecting medium between man, the earth, and the heavenly bodies, and also between man and man. (2) Disease originates from the unequal distribution of this fluid in the human body; recovery is achieved when the equilibrium is restored. (3) With the help of certain techniques, this fluid can be channeled, stored, and conveyed to other persons. (4) In this manner 'crises' can be provoked in patients and diseases cured" (Ellenberger 1970, 62).

${ }^{9} \mathrm{~A}$ third element of Mesmer's system was the analogies given by the contemporary discoveries in the field of electricity. Mesmer imagined his fluid as having poles, streams, discharges, conductors, isolators and accumulators. His baquet, an instrument that was supposed to concentrate the fluid, was an imitation of the recently invented Leyden jar. He also taught that there was a positive and a and a negative fluid that neutralized each other an assumption that was never accepted by his disciples (Ellenberger 1970,63).

${ }^{10}$ At the beginning of 1852 the wave of spiritism passed cross Atlantic and reached England, Germany and then France (Ellenberger 1970,47). 
conscious. The first one is the traditon of cognitive unconscious whose origin is found in Leibniz's philosophy, more precisely in his notion of petites perceptions. This tradition referred to perceptions which were too weak to become conscious. Later on it was influenced by Friedrich Herbart (1776-1841), who came up with the notion of Schwellengesetz (law of the threshold) who spoke of suppression of some perceptions, which - as he believed - can get back to consciousness. In the $19^{\text {th }}$ century it was Gustav Theodor Fechner (1801-1887), Hermann von Helmholz (1821-1894) and Theodor Lipps (1851-1914) who belonged to it. The second tradition was romantic tradition and according to Göde it "arose from the fear that the Enlightenment would stagnate into a flat and lifeless rationalism, if the emotional, natural, biological, fantastic, and irrational dimensions of human experience were not taken into account" (Göde 2010, 263). Whereas Ellenberger (who does not conceive any ramification of concepts of unconscious and considers Romantic tradition as the only one) associates beginning of this tradition with Schelling's Naturphilosophie and some crucial concepts of Johann Wolfgang Goethe (1749-1832) (Ellenberger 1970, 23-24), Göde links the beginning of this tradition with thinkers like Johann Georg Hamann (1730-1788) and Johann Gottfried Herder (1744-1803). According to Göde, Schelling reassumed these thinkers and it was - still during Schelling's life - Carl Gustav Carus, who put forward the first systematization of this Romantic or vitalist understanding of unconscious in his work Psyche: Zur Entwicklungsgeschichte der Seele (Psyche: On the Developmental History of the Soul, 1846). The third tradition was developed in opposition to two currents of post-Kantian thought: 1) idealistic philosophy of reason associated with Johann Gottlieb Fichte (1762-1814) and Georg Wilhelm Friedrich Hegel (1770-1831), 2) Schelling's philosophy of nature (Naturphilosophie). Göde denominated this tradition as "drive-related irrational" (triebhaftirrationale) tradition of unconscious. This tradition emerged from Schelling's redefinition of will as impulse (Drang), instinct (Trieb) and desire (Begierde) and led to recognition of dangerous or destructive impulses and urges in the human nature. This tradition embraced metaphysics of several German thinkers: 1) Schopenhauer's Wille zum Leben, 2) Eduard von Hartmann's metaphysics of unconscious and 3) antimetaphysical notion of "will to power" of Friedrich Nietzsche.

As stated above, Carus is identified within the Romantic current of Naturphilosophie, however, he was no theorist. On the contrary, in his time Carus was wellknown as a court physician of the King of Saxony and a quite important figure of German Romanticism. He studied medicine because of his interest in the science of nature, started lecturing and received his doctorate already in the age of twenty-two. In 1814 he became Professor of Gynecology and directed the obstetrical clinic. His books were frequently translated into English as for example An Introduction to the Comparative Anatomy of Animals (1818 in German, 1827 in English). As a court physician he had great opportunities to travel all over Europe and 
made friendship with forty years older Goethe who recognized him encouragingly. Later Carus published book Goethe (1843) and letters on Faust (1835). Goethe - as in the case of Jung - represented a significant influence for Carus and according to Hillman, was his spiritus rector (Hillman 1989, ix). Goethe himself was unreservedly enthusiastic over Carus' psychological thoughts, especially in his Vorlesungen über Psychologie, gehalten im Winter 1829-1830 zu Dresden (Lectures on Psychology, 1831). Even if forgotten soon after his death, Jung reminds him repeatedly as one of his own key precursors and inspirators, especially because of Carus' thoughts of unconscious that "had gone down under the overwhelming wave of materialism and empiricism, leaving hardly a ripple behind it, it gradually reappeared in the scientific domain of medical psychology" (Jung CW9, 1, para.1). In the next chapter I will take a more detailed look at Carus thoughts about psyche.

\section{Carus' Soul: Holistic Unsconscious as the Archetypal Background of Being}

All attempts to separate the soul from the palpable organism and distinguish it from organic life will fail. We will always consciously see the soul as being most closely linked to all the forms of our life.

Carus $^{11}$

As we have already seen neither $18^{\text {th }}$ nor $19^{\text {th }}$ century philosophy produced clear and coherent theory of unconscious. Ideas about unconscious aspects or unconscious dimension of human soul were only by-products of general theories of mind/soul (Leibniz, Hamann, Kant, etc.). According to some, it was Carus who proposed the first theory of unconscious within the field of study of psychology. For Bell, Carus "has a strong claim to be considered the first proper theorist of the unconscious. (...) No one before Carus makes the unconscious central to a theory of mind.(...) From this point onwards the unconscious becomes an unavoidable issue in German psychological theory" (Bell 2010, 156) and for Ellenberger Carus's Psyche "was the first attempt to give a complete and objective theory on unconscious psychological life" (Ellenberger 1970, 207). Moreover, it seems that Carus outlined clear definition of psychology as an independent science studying the development of soul from the unconscious to the conscious making use of Fechner's famous model of "iceberg" where soul is described as layered substance with various layers of unconscious. Even though Carus is not totally dedicated

11 (Carus 1989, 6). 
to the study of unconscious ${ }^{12}$, in his model unconscious has primacy and precedence regarding consciousness:

\begin{abstract}
"The key to the knowledge of the nature of the soul's conscious life lies in the realm of the unconscious. This explains the difficulty, if not impossibility, of getting a real comprehension of the soul's secret. If it were an absolute impossibility to find the unconscious in the conscious, then Man should despair of ever getting a knowledge of his soul, that is a knowledge of himself. But if this impossibility is only apparent, then the first task of science is to state how the spirit of Man is able to descend into these depths" (Carus 1989, 1).
\end{abstract}

As it is seen from the first phrases of Carus's work Psyche, his thought is based on the basic thesis of romantic medicine and philosophy, that "developed consciousness (...) never frees itself from its biological basis" (Bell 2010:167), i.e. thesis later on findable both in Freud and Jung. Nevertheless, Carus is today almost completely forgotten representative of German psychological theory and his psychology is today rarely read. It was Jung who, in the $20^{\text {th }}$ century, popularized his work. Carus reached fame as a painter, gynaecologist, scientist who made two significant discoveries in the field of zoology. Perhaps that is what saved him from total oblivion. It is paradoxal that at the time of its publication Psyche has achieved considerable success and influence: Goethe read it shortly before his death, Dostoyevsky thought about translating it into Russian. This work infuenced also Georg Groddeck, a pioneer of psychosomatic medicine about whom Freud was convinced that used term "id" (das Es) for the very first time. It is quite clear that Carus anticipated Freud (conflict between consciousness and unconscious) or Schopenhauer.

Romantic or holistic aspect of his psychology cannot be disregarded. Carus' thought takes place within Schelling's Naturphilosophie. He made a stand for series of philosophical positions opposing Cartesianism: “(...) rejected the division between organic and inorganic matter, viewed the universe as an organism, not a mechanism, and treated the philosophy of nature and philosophy of mind as complementary parts of one system. The essence of nature is that it produces subjectivity which enables it to understand itself. (...) psychology's job is to trace the emergence of subjective consciousness out of nature, and the medium for this is the unconscious. For Carus, then, as for Schelling, the unconscious is 'not yet conscious self' (noch nicht bewußtes Ich). In psychology, Carus' aim would be to discover the unknown, unconscious productivity behind all consciousness" (Bell $2010,163)$. These phrases reveal quite strong dose of anti-Cartesianism but also

12 "That Carus is more interested in consciousness than in the unconscious is amply demonstrated by the observation that Part Two encloses more than $75 \%$ of the work's bulk" (Stein 1989, 75). 
of holism. As we will see in final chapter this holism contains considerable similarity with Plato's anima mundi, i.e. that aspect of soul one can find both in Plato and Jung as well. Such a holistic stance is perhaps even more apparent in the following quote where the opposite relation between spirit and matter is literally erased:

\begin{abstract}
"That the movement of the stellar bodies, the orbit of the planets and comets and moons, was in just the same measure an annunciation of life as were the metamorphoses of plants and the circulation of the blood corpuscules in the animal spirits in this insight I had experienced the liberation of my spirit from the dark cramped ideas of a dead mechanism, and the desire to proclaim the triumph of this knowledge and bring it to the attention of the world motivated me above all other things" (Carus 1848, 442).
\end{abstract}

This holism is emphasized by today's post-Jungians which is also because for them concept of soul acquired pre-eminent importance. Founder of archetypal/imaginal school James Hillman emphasizes that psychic and natural processes are considered by Carus as parts of one process and that is the gist of his holism. In this sense, Carus is a thinker who thinks beyond polarity spirit - matter. In this respect Carus is Jung's precursor (Hillman 1989, xi). Carus "describes psychological processes in detail and yet holds to a holistic view, placing the unconscious and psyche within a meaningful universe whose main focus for him is 'life'" (Hillman 1989, vii-viii). For him Carus "moved outward [the matter] into holistic principles (...) attempted to hold together the two sides [spiritual and material] of his nature, and thus of nature itself. For him the particular was always an aspect of the general, the microcosmic and microscopic a display of a meaningful macrocosm (...)" (Hillman 1989, x-xi). For Hillman, Carus is a great opponent of empirical materialism, a representative of romantic medicine that "differs from the fantasy of what we euphemistically call 'scientific' medicine chiefly in regard to the significance of the soul" (Hillman 1989, x). Carus's concern for soul is exactly why he "sees man primarily as a psychological being, through whose unconscious he is connected with all life both as nature and as that spiritual principle which inheres in and transcends nature" (Hillman 1989, viii).

But it would not be correct to see Carus only as a Schelling's follower - and in a sense, Plato's - and predecessor of Jung or Hillman. In many respects Carus is Aristotelian thinker, a fact perceptible in his descriptions of intrapsychic processes of "becoming" (Werden), for instance when consciousness emerges from unconsciousness, processes that - as Carus himself says - he understood in accordance with Goethe and Herder (Bell 2010, 164, note 28). But some link Carus' evolutionary biological model rather with Aristotle and his theory of five souls. According to Aristotle, each of five souls has different capacities (dynameis). The elementary one, vegetable soul, has the capacity of nutrition and growth, the 
second type has capacities of the vegetable soul and capacity of perception. The third type has capacities of two preceding plus desire. The fourth has the above plus movement. And the fifth type contains all the previous plus "intellect and the reflective capacity" (nous kai he theoretike dynamis) (Bell 2010, 164). Carus proposes a similar model in which a soul passes through several stages where each one contains the previous ones.

In his main psycho-philosophical work Psyche Carus aims to "establish (...) that the divine component in our deepest being unfolds itself from the unconscious to consciousness (...) to assert that the key to an understanding of the nature of the conscious life of the soul lies in the sphere of the unconscious" (Carus $1989,9)$. Of course, such a dynamic connection between consciousness and unconscious is apparent in the process of development, growing or changing of human body and soul. According to Carus, life of human soul can be divided into three fundamental periods. In two of them human soul is completely unconscious:

\begin{abstract}
"The first period is the latent existence of the ovum. The ovum lies in the most secluded depths of the healthy maternal organism from birth, quite inseparable from the mother's life, without any perceptible change, unique in itself for two or three decades, and, of course, without the slightest trace of a higher psychic life. Then, awakened by the living interaction between the male soul and maternal soul, the second period in the life of the growing child begins within the mother's womb. (...) Here again there is nothing to suggest any dawning of consciousness. Nothing in our mature psyche therefore exists that could be called a memory of that life, a reminiscence of our second period of life. The being itself, the entire itself, the entire effect of the divine spark, that inner primordial image, is revealed at this unconscious stage only as a mysteriously creating power. (...). The third and truly human period of life starts with birth. (...). From then on, despite periodic returns to the unconscious, the particular world of the self-conscious, feeling, willing and discriminating soul develops with advancing maturity out of that early unconscious state" (Carus 1989, 2-3).
\end{abstract}

In this extract from the introduction to Carus' work Psyche one can see that this German thinker's human soul never ceases to be unconscious and somewhat governed by laws of the unconscious. Expressions like "inner primordial image" or "divine spark" remind us not only (post-)Jungian concept of archetype but also Goethian Urbild or Plato's eidos ( $\varepsilon\llcorner\delta o \varsigma)$ : "In my system the divine, which contains the primary basis of individual life is called the idea or the primordial image (...)" (Carus 1989, 8). But it would be error to consider Carus' soul as a spiritual or metaphysical substance. Carus repeatedly reminds us that the soul - which he considers forming, shaping and nourishing essence of everything alive (Carus 1989, 4), or simply "life force" - "is the primary act of a physical body capable of life" (Carus 1989,4$)$. This quote from Aristotle's De Anima can serve as a proof not only of 
Aristotelian aspect Carus' thought but also that his concept of soul is a na-tural and mainly unconscious - phenomenon that appears everywhere where li-fe appears. Carus' concept of soul is also a proof of how much Aristotelian thought influenced German philosophy and science in $19^{\text {th }}$ century. However, Carus' wellknown work Lectures on Psychology (Vorlesungen über Psychologie, 1831) exhibits his concept of soul as much more complicated. However, similarly to Aristotle, he links soul with the biological basis of the body. Carus rejects all the theories that deny such link or, in other words, that separate conscious life from that of the body and instinct:

\begin{abstract}
"Error and discord arose in those theories only when the soul was severed from life and attempts were made to introduce the most abstruse concepts about life. (....) This intellectual development was only part of the reason why the soul was not seen to be the first reality of a natural, systematically arranged body. The other part of the reason is that a barrier stood between the unconscious and consciousness, shutting out everything not conscious from the realm of the soul" (Carus $1989,4-5)^{13}$.
\end{abstract}

In Carus Aristotelian inspiration is quite apparent in the way he explains interacttion between temporal matter/body (Aristotelian matter) and immortal divine/spark or soul (Aristotelian form):

"In our thoughts we can separate many things which are never separated in reality. We can differentiate in every creature, as Aristotle says, '...one element, matter, which of itself is no particular thing; another, the form of species according to which it is called 'this particular thing'; and a third, that which is from both of these. The material element is potentiality, and the formal element is actuality' (De Anima II, 1.). In a living creature - a creature which is self-developed, self-sustained, self-nurtured, and self-moving - it is primarily the divine spark that determines the form. (...) The form, called by Aristotle the actuality of the object, is generally constant and evenly sustained throughout life by the divine spark. Matter, called potentiality by Aristotle, continually changes, is lost, and has to be replaced" (Carus 1989, 7-8).

Carus again turns against willful separation between matter and idea/primordial image which was so typical for Cartesian philosophy. In fact, he finds such approaches dangerous:

“(...) these divisions are arbitrary. We can never separate them objectively. Form without matter and without an idea to govern it is impossible; matter without form

13 Carus does not include in this group of medieval thinkers Thomas Aquinas. For him Aquinas' concept of soul did not constitute threat of its immortality (Carus 1989, 5). 
is again an impossibility; and an idea, a primordial image, which is not active in any form, not reflected anywhere, cannot exist. (...). Nevertheless, this kind of thinking is very dangerous. We could easily grant these notions some reality. The result would be an abstruse and most unsatisfactory concept of the world and man" (Carus 1989, 8).

Or, elsewhere Carus rejects body-soul dualism:

"For more conclusive proof and a demonstration of the oneness rather than the duality of the essence on which our whole being is based, consider the following. Unawareness of the cause that forms and nurtures life does not prove the differrence between it and the soul. For although much that goes on in the organism never becomes conscious, everything that happens there has at least an least an indirect effect on consciousness. The entirely unconscious functions responsible for the growth and form of the organism as an embryo are connected to consciousness in that they create organs which later receive, retain and modify images. Other functions which are only partially unconscious, such as blood circulation, growth, excretion, etc., have still more influence on consciousness. In illness some of them intrude directly on consciousness. There is no firm barrier between the soul and the so-called life force" (Carus 1989, 6-7).

It is necessary to add that above mentioned Carus' three stages of soul's development correspond with two levels of the unconscious soul and two levels of consciousness: 1) absolute unconscious (absolut Unbewuwußtes) and 2) relative unconscious (relativ Unbewuwußtes). Relative unconscious is further divided into "general absolute unconscious" (allgemeines absolut Unbewuwußtes) a "partial absolute unconscious" (partielles absolut Unbewuwußtes). Carus divides conscious psyche into: 1) consciousness of world (Weltbewußtsein) and the more developed 2) consciousness of self (Sebstbewußtsein). For Carus the most important level of the psyche is a relative unconscious ${ }^{14}$. Carus' psyche is fundamentally biological - as for Aristotle ${ }^{15}$. Its deeper levels are not only unconscious, but have biological quality as well. But this is not the only characterization of Carus' unconscious. Just like Leibniz before him and Jung after him, Carus says that the uncon-

14 "That is the place where the most intense mental activity takes place. Carus denotes it as a relative unconscious because it is not in fact totally unconscious. Major part of it is constituted by conscious experience which was forgotten. All forgotten memory returns back to relative unconscious immediately after leaving the consciousness. It is interesting that whereas it seems that Carus believes that nothing is totally forgotten or erasured from the memory; all the thoughts are preserved in one or another form" (Bell 2010, 167).

15 That is why Bell and other authors consider Carus' concept of soul consider not only Aristotelian. Carus repeats Aristotelian principle: the lower soul is contained in the upper soul. 
scious soul is constantly active: "it is, to a certain extent, continuous, it is constantly re-forming, always destroying and renewing" (Bell 2010,166). At the same time Carus' unconscious dimension of soul has, somehow, divine qualities - qualities of "immovable driving force" or "life force".

\begin{abstract}
"Life force, formative instinct, or whatever name it bears, must always and in all its forms be self-moving, not moved by outside factors. Therefore it must share in the divine, since the divine is always and essentially unmoved, moving itself and others from within itself. The same thing, however, has to be said of the soul itself. Thus, any attempt to find characteristics that would establish lasting and incontestable differences between the life force and the soul end in a vicious circle. The life force, however it may be imagined, will always remain self-moving, something individual, driven only by the breath of the divine - in a word, a kind of soul" (Carus 1989, 6).
\end{abstract}

According to Bell, Carus' concept of the soul falls within Leibniz-Wolff tradition, but at the same time there is an influence of Schelling's Naturphilosophie and biologism deriving from Carus' own concept (Bell 2010,168). As it was already mentioned, Carus differentiates consciousness of the world (Weltbewußtsein) and consciousness of self (Selbstbewußtsein). Such a differentiation reminds $18^{\text {th }}$ century philosophers' difference between empirical consciousness and reason ${ }^{16}$, but, on the other hand, there are many aspects where Carus' biologism is quite evident $^{17}$. In fact, Carus - probably inspired by Schelling - arches over previous soulbody dualism and declares natural body-soul/psyche continuum:

"Mind [Geist] is not something apart from nature, it is only nature's purest creation and therefore its symbol, its language." [der Geist (ist) nichts von der Natur Verschiedenes, nur ihre reinste Ausgeburt und daher ihr Symbol, ihre Sprache] (Carus, 1831, 39-40).

In this respect one can agree with some critiques according to which Carus is rather philosophical than psychological thinker ${ }^{18}$. This philosophical aspect is apparent especially where Carus uses already mentioned expressions "life force",

16 "Whereas traditionally German philosophers, following Descartes and Leibniz, had distinguished between empirical consciousness and reason, Carus replaces reason with consciousness of self. In this respect, he follows his master Schelling" (Bell, 2010, 168).

17 Consciousness of the world (Weltbewußtsein), for example, requires four indispensable prerequisites which reveal his strong biologism. Weltbewußtsein stands for sensory faculties, i.e. five senses and sense of warmth but at the same time it is constantly exposed to unconscious.

18 'Carus' psychology was more philosophical, within the terms of Schellingian idealism, than it was properly psychological" (Bell 2010, 171). 
"soul", "primordial image" or where he tries to show that psyche does not belong to the individual but to genus:

\begin{abstract}
" $(\ldots)$ if the soul and life force were truly and essentially different, no sense organ could affect the mind, nor could the mind itself affect the body. Thus everything suggests that a unified life principle, something self-moving - Aristotle's entelechy, Plato's idea, or a psyche, a soul, something divine, call it what you will - is the basic condition of all life, and therefore of all living forms. (...) We should thus recognize something divine in every living creature. It forms the very essence of life. We must perceive it as the basis of the creature's reality. This is what we call the idea of its being, or the soul" (Carus 1989, 7).
\end{abstract}

Even though Carus is apparently much more biological than Schelling, one can see in his thoughts a well-known Schellingian principle "Nature is visible Spirit, Spirit is invisible Nature", that leads directly to holistic conception of human being and soul. For him, expressions like "life force", "soul", "primordial image" are equivalent of "divine". In fact, they are quite close to what Schopenhauer termed as "Will" or what Jung termed (in his 1926 diagram of the human psyche) as a "central fire" about which Thomas Singer says following:

"(...) inside each human being the psyche connects the individual to the history of life's evolution, from human to the history of life's evolution, from human to primate to the very origin of life itself (...)" (Singer 2012, 2).

Another common feature of Jung and Carus is a category of archetype. For Jung, archetyp is cognizable especially thanks to (but not only) archetypal images or imagery whose equivalent in the Goethe's romantic philosophy is called primordial image (Urbild). If Carus speaks of divine as a deepest dimension of unconscious psyche, he frequently uses expression "primordial image": "in my system the divine, which contains the primary basis of individual life, is called the idea or the primordial image (...)" (Carus 1989, 8).

It is remarkable that even though Carus' book Psyche makes use of unconscious mainly as a way to explain consciousness, its author is convinced that understanding of unconscious is a prerequisite of understanding of conscious life. According to him this book is an

“(...) attempt to establish the following point of view: that the divine component in our deepest being unfolds itself from the unconscious to consciousness. (...) we wish to assert that the key to an understanding of the nature of the conscious life of the soul lies in the sphere of the unconscious" (Carus 1998, 9).

Do these words reflect certain presentiment of later well-known concept of recapitulation of phylogenesis in ontogenesis as it is present both in Freud, Jung and 
others (Bell 2010,165)? In any case, a root-idea of conscious life as a growing out of unconscious was confirmed and later in more detail developed during the $20^{\text {th }}$ century.

\section{Soul Today: From Vitalist to Imaginal}

[Freud] demonstrated empirically the presence of an unconscious psyche which had hitherto existed only as a philosophical postulate, in particular in the philosophies of C. G. Carus and Eduard von Hartmann

Jung 19

The mortality of all living beings, their metastable shorter or longer dance upon the lifeless, into which they must return." This is a most illumining metaphor. Life as such is a dance. (...) And a movement on the lifeless, using it as a "base", so to speak. Life is obviously real, but nevertheless nothing ontological, not "something", a subsisting entity. It is invisible and intangible. True, we can see and touch living beings, organisms, and see that they are alive. But living organisms and their life must be distinguished. The latter we cannot see.

Giegerich $^{20}$

If Jung repeatedly refered to Carus (as well as to von Hartmann or Goethe) he did so to point to romantic roots of his own thought (and therapy). Ellenberger repeatedly reminds us the same roots when quoting Liebbrand's statement according to which "C. G. Jung's teachings in the field of psychology are not intelligible if they are not connected with Schelling" (Ellenberger 1970, 204). The same states Claire Douglas when saying that Jung's ideas about collective unconscious, its archetypes, anima-animus syzygy "were inspired in part by F. W. von Schelling's (1775-1854) impassioned philosophy of nature, his concept of the worldsoul which unified spirit and nature, and his idea of the polarity of masculine and feminine attributes as well as our fundamental bisexuality" (Douglas 2008, 25). Next to Schelling, Goethe, Schopenhauer, Bachofen and Nietzsche Douglas reminds Carus's concept of unconscious as directly preceding Jung's concept of collective unconscious: "He saw the life of the psyche as compensatory and where

19 (Bell 171, note 61)

20 (Giegerich 2012, 27) 
dreams play a restorative role in psychic equilibrium. Carus also outlined tripartite model of the unconscious - the general absolute, the partial absolute, and the relative - that prefigured Jung's concept of archetypal, collective, and personal unconscious" (Douglas 2008, 26). There is much more similarities between Carus, Jung and post-Jungian tradition. Let's remind also Carus's tripartite model of evolution (1. a pre-embryonic period, 2. the embryonic period, 3. period after the birth during formation of unconscious continues) that resembles (at least partly) today's concepts of individuation (Stein 2006, 196-214). Also the way he characterizes the unconscious is similar to Jung's - for Carus unconscious 1) has "Prometheic" aspect and "Epimetheic" aspect at the same time, 2) it is in constant movement, 3) it is indefatigable, 4) it does not know disease and disposes of healing power of nature, 5) consciousness depends on unconscious. All these characteristics of unconscious are findable in Jung and post-Jungians as well. Also the role of psychology as understood by Carus resembles Jung's approach: science of the soul's development from the unconscious to the conscious. Insisting on the importance of soul, Carus is also very close to Wolfgang Giegerich (event though he cannot be called romanticist) according to whom: "With the disappearance of the metaphysical concept and definition of the soul the soul itself did not disappear. It merely underwent a form change. It entered a different logical status. It is a positivistic fallacy to think that the negation of the metaphysical soul to nothing at all, so that psychology lost its object altogether" (Giegerich 2012, 20).

As it was already stressed Carus' model of psyche draws significantly from Aristotle according to whom "the soul [is] life principle, [because for him] the soul is primarily the entelechy of the body, i.e., the form which actualizes itself in the movements and changes of a living organism (...). In this sense, the Aristotelian notion of soul is, (...) essentially tied to the body and its vital functions (...)" (Giegerich 2012, 267). Giegerich even affirms that Aristotle's concept of soul did not contain early modern (Neuzeit) differentiation between "interior life of the soul/subjectivity" and "external reality" because Greeks did not view psychological processes as exclusively subjective and personal, but as cosmic processes:

\footnotetext{
"The Greeks certainly had the word I in their language and of course made use of it in everyday speech. They of course also made a difference between body and soul. But the distinction so characteristic of the early modern period between 'the inner' as a world of its own and 'external' reality, did not exist. For Aristotle, for example, the science of the soul (psyche) is a part of 'physics'. Emotions like anger and erotic desire, functions like thinking and seeing are cosmic processes, just as rain, thunder, earthquakes, or sunshine are. This is also why affects, somewhat surprisingly, were called pathê or pathêmata ('what happens to ...'), passions animae, Leidenschaften, in other words, they were not not perceived in terms of the I as its own self-expression, its feelings and desires" (Giegerich 2012, 274).
} 
It is true that Jungian tradition does not use term "cosmic process", but works with concepts of "collective unconscious" and anima mundi. The first one draws from romantic, e.g. anti-Enlightenment tradition and the second one from Plato. Moreover Plato's anima mundi is a concept not too distant either from Aristotle or from Carus because it links the soul with physical life of the body:

\begin{abstract}
"The idea of a world soul is the fourth aspect to be mentioned from Plato's thinking about soul. Plato proposes a view of cosmos as a large animal whose 'soul' is the impetus and guide of the movements of nature. It follows from this conception that everything that is alive has a soul, even animals and plants. This, the soul as life principle, became a major concept for Aristotle (...). For him the soul is primarily the entelechy of the body, i.e. the form which actualizes itself in the movements and changes of a living organism, or which is that which makes an organism be what it is. In this sense, the Aristotelian notion of soul is, to begin with, essentially tied to the body and its vital functions, which is in open contrast to all that I stressed before about the soul as absence, negativity and as fundamentally underworldly or metaphysical existence" (Giegerich 2012, 267).21
\end{abstract}

It seems that in times of Romanticism these both traditions - Platonic anima mundi and Aristotelian vegetative aspect of the soul - started to intertwine with Romantic concepts influenced by Goethe and Schelling. As it is known, Freud was also under the significant influence of this current and only in times of his medical studies (1873-1881) "like many other natural scientists of the late nineteenth century, (...) implemented a shift from a philosophy of nature to a materialistic world-view" (Gödde 2010, 265). But that did not take place neither in Jung nor in Jungian tradition where less orthodox current, archetypal/imaginal psychology not only rejected structural model of psyche (Adams 2004a), but also adopted Hillmanian programmatic slogan "stick to the image" which follows the connection Jung's makes between image and soul: "The psyche creates reality every day. The only expression I can use for this activity is fantasy" (Jung 1953-1991, CW 6:52, par. 78) and Addams adds: "If, as Jung succinctly says, 'image is psyche' and if psyche crea-tes reality, then what creates reality is the image. Rather than say that the psyche, or the image, 'creates' reality (which might imply that the activity of fantasy creates reality ex nihilo), I myself prefer to say that it constructs reality. Thus I emphasize what I call the psychic contruction of reality, or the imaginal con-struction of reality" (Adams 2004b, 5-6).

Thus Jung - who considered himself a Carus' inheritor - is a forefather of the school of archetypal/imaginal psychology, which considers "psychic image" a true

\footnotetext{
${ }^{21}$ Nevertheless Giegerich adds that these are only "vegetative aspects" of Aristotelian soul: "There is an additional dimension of the soul which comes to the fore only in man" (Giegerich 2012, 267).
} 
carrier of unconscious soul/psyche. From this perspective, image is not separated from the "vegetative" aspect of the soul or instinct but on the contrary it mediates it to upper, i.e. more conscious levels of the soul. Even though Erich Neumann was not a representative of archetypal school, he succinctly expressed an importance of the psychic image when studying history of consciousness and the role of an archetype in it. For him, both archetype per se and archetypal image have biopsychic aspect. Needless to say that Neumann follows Carus' that according to whom "developed consciousness (...) never frees itself from its biological [e.g. unconscious] basis":
“(...) the dynamic action of the archetype extends beyond unconscious instinct and continues to operate as an unconscious will that determines the personality, exer- ting a decisive influence on the mood, inclinations, and tendencies of the persona- lity (...). When the unconscious content is perceived, it confronts consciousness in the symbolic form of an image. (...) even the instincts, the psychic dominants, which of all unconscious contents are most important for the psychological totality, seem to be linked with representations of images. The function of the image symbol in the psyche is always to produce a compelling effect on consciousness. (...) The re- presentation of the instincts in consciousness, that is to say, their representation in images, is one of the essential conditions of consciousness in general (...)" (Neu- mann 1983, 4-5).

In The Origins and History of Consciousness Neumann attempted to smuggle his discoveries regarding archetypal imagery in historiography in the form of psychohistory: "If we offend against 'history' by removing documents and representations from their cultural context, we hope to compensate by correlating our archetypal investigation with a 'psychohistory', that is to say, with the stages in the development of the human psyche" (Neumann 1983, 89). "History is a series of images, tales, geographies, figures, lessons. It's not so much fact" (Hillman 1983, 80 ). Even though his success - as well as success of others - in this field was limited, "image" remained still in the center of Jungian tradition's attention and today some speak about "imaginal essentialism". Supposing that images are essences containing information about unconscious processes, Jungian analysts use three methods: 1) explication, 2) amplification and 3) active imagination to translate and to understand psychic, i.e. encyphered images. That is the way how analysis uncovers what David Bohm calls "implicate order" of the unconscious psyche:

"When Jungian analysts explicate an image, they interpret it in terms of what it essentially implies. In explication, the assumption is that an essence is implicit in the image and that the purpose of interpretation is to make that essence explicit. Jungian analysis assumes that the imagination has what David Bohm calls "impli- 
cate order". By the method of imaginal essentialism, Jungian analysts render that implicate order into an 'explicate order '” (Adams 2004, 15).

Even though later generations of Jungians turned away from its maitre with critical distance ${ }^{22}$, it seems that in their conceiving the relation between instinct, soul and image they refer to Jung and thus to Carus as well. In this respect it is symptomatic that Hillman's commentary to Jung's lecture was entitled "Psychological Factors Determining Human Behaviour" (1936) where he is concerned about psychology-biology relation ("the relation between instincts and the psyche", Hillman 1997, 31) and sustains that on the one hand instinct is separated from the psyche and on the other hand it is subject to "psychization":

"He regards the instincts as older than, prior to, and outside the psyche (ectopsychic) and characterized mainly by compulsiveness. Instinct is subject, however, to 'psychization',that is, instinct may be modified through and by various psychic structures. The psychization of an instinct yields the coloring of it that we see. That is the instinct as experienced, felt, and observed in behavior. Because the instinct an sich is ectopsychic, it is objectively given by biological nature and may be conceived like the objective wave length producing the sensed experience of color. (...) Psyche can tame the compulsions (or intensify them), can postpone release, and can shift the goals of satisfaction. Whatever we know of instinct in ourselves has already been through process of psychization. We have only those perceptions of instinct which have been filtered through the prism of our psyche" (Hillman 1997, 32-33).

It even seems that - because Jung pays special attention to what he considers "creative instinct" - creative life requires continuous development of creative possibilities latent in each of us. But in contrast to Carus, for Jung instinct-psyche continuum is not totally fluent and psychization of instinct can be a difficult task: "The ectopsychic instinctual force, because it comes from beyond the psyche, is more than human and mightier than its possessor. Its possessor is, in fact, always in danger of possession.(...). One spends one's life trying to slow it, tame it, give it enough time and space, because its haste is the destructive devil within the creative impulse itself" (Hillman 1997, 36).

22 Such a critical distance is associated with James Hillman during 1960s. Various apects of Hillman's thought differ from that of Jung: “(...) I don't emphasize, or even use, some of Jung's terms, like: self, compensation, opposites, types, psychic energy. You won't find anything about mandalas and wholeness, and I don't refer much to Eastern thought, synchronicity, and the Judeo-Christian God-Image. My favourite books are not Aion and Answer to Job. When I use term 'ego', I put ironic marks around it: the so-called ego, because for me the task of psychology is to see through it and get around it. I certainly don't place this construct, ego, in the center of consciousness" (Hillman 1983, 30-31). 
Diagnosing modern man psychology Giegerich refers to modern man as a fundamentally blind to reality of the soul and to soul-truth. Whereas premodern man was aware of soul as objective and nature-based, modern man or "born man's" experience and subjectivity (ruled, as Giegerich says, by the human-all-too-human) is "emancipated" from the soul:

\begin{abstract}
“For born man, neither Heaven nor Earth, neither 'sun' nor 'eye' (in Plotinus' or Goethe's sense) exist. The whole natural world is over. Heaven has, as Jung repeatedly pointed out, itself become positivized into the universe of the physicists, and Earth has become intellectualized; it dissolved into ideas, constructs, computer models, mathematical formulae. [In premodern times] mythology was the expression of the innermost logic or truth of actually lived life at the time of a nature-based life. What in the transition to modernity has changed is the medium or element in which the soul of the Real is immersed. In the former times the medium was Nature. Life was fully governed by and integrated into the natural sequence of day and night and the seasons, of birth, life and death (...). Now that the soul has been born out of nature, that it has - logically, psychologically - left nature, substance, and content fundamentally behind itself (...), now that man has been able to go to the moon and, via satellites, essentially looks down upon the Earth from outer spa-ce, now that he manipulates the innermost constitutution and workings of nature itself (...) and lives and thinks on a very abstract level of functions, logical relation-ships, structural forms, now mythic imagination has fundamentally become incapa-ble of expressing the soul" (Giegerich 2012, 149-151).
\end{abstract}

Consequently modern man's subjectivity is cut off from its deeper soul-roots, separated from the nature and from the nature of the soul, soul's thruth: "The logos eôn, the soul's truth, is not released into its being true. The 'sun' is there, but 'eye' is lacking. (...) The modern blindness to and dissociation from the soul is the prevailing state of affairs, but it is wrong. Why? Because the soul's emancipation from itself, modern man's bornness [is soul's emancipation] from the soul in its former natural form, not from soul as such" (Giegerich 2012,153).

In Giegerich's view the consequence of above mentioned "modernity emancipation" created opposition - and not continuity - between soul and ordinary human experience. Giegerich compares modern subjectivity to the "wilderness of the soul" or "oasis in the desert of the soul" (Giegerich 2012,153) and threatened both from above and from below by the natural or "inhuman" soul (Giegerich 2012, 154):

"It is as if it were an island or a walled garden, a safe place of civilized life to be led
under familiar conditions. It is the middle between two extremes. (...) In the mo-
dern Western world, most of our daily life takes place in this sphere of relative irre-
levancy and liberalism, the sphere of emancipation from soul. This safe island or 
garden is 'threatened' on both sides ('above' and 'below') by the incursion or manifestation of the soul, the 'inhuman' soul" (Giegerich 2012,154).

Where there was at least a relative continuum (Carus, Jung, Hillman), now there is a scheme of a relatively small region of modern "human subjectivity" threatened by "inhuman soul". This scheme is not totally in contradiction with Hillmanian rendition of Jungian tradition ${ }^{23}$, but leads beyond it. "Above" stands for forces of light, noble and ethically "good" side of soul, "below" refers to demonic and possibly destructive unconscious forces of darkness. In this respect Giegerich represents tight link with Hillman and Carus. "Lower soul" is uncivilized, pathological, instinctual, explosive and civilization-threating soul. What for premodern times was a domain of underworld deities and hell, in $21^{\text {st }}$ century archetypal psychology terms lower, instinctual soul that "disturbs our peace of mind by plaguing us with neurotic, irrational anxieties, obsessions, compulsions, psychosomatic impulses, depressions, and so on" (Giegerich 2012, 155). Here we have a biological, natural, non-ego sphere that verges on pathological. "From below" is observable psychologically and socially ${ }^{24}$ and stands on the very beginning of the depth psychology: "Historically, the 'from below' gave rise to the early psychological ideas of the subconscious and the unconscious (which was also usually located "beneath" consciousness, at least in the early days of psychology" (Giegerich 2012, 155).

As it was already mentioned, Carus stands at the very beginning of psychophilosophical conceptualization of soul where lower dimension of the soul was understood as the very origin of conscious life. Carus' "biological soul" can be seen as a direct forerunner of Hillmanian or Giegerichian "lower" and "unpsychized" dimension of the soul.

Carus' insights played a significant role in Jung's concept of collective unconscious, the way he viewed the role of the instinct/archetype/primordial image in psyche and the historical structuring of deeper layers of psyche. Jung's "heir apparent" Erich Neumann further elaborated historical structuring of the psyche in his studies about archetypal stages of the evolution of consciousness throughout history. In his groundbreaking The Origins and History of Consciousness

${ }^{23}$ For Hillman soul conceived as 1) an perspective and not as an essence, 2) has an intimate link with death, 3) has a natural relation to depth and to aprofound itself (Heraclitus). For Hillman - as for Jung or Giegerich - whole field of psychology was approached from the pathological: "My point is that soul means inferiority - something sensitive, something ...well ...pathologized. Soul makes the ego feel uncomfortable, uncertain, lost. And that lostness is a sign of soul" (Hillman 1983, 17).

24 (...) "on political level, whole nations can go mad and systematically commit terrible atrocities, just think of Nazi Germany and Rwanda a few decades ago" (Giegerich 2012, 155). 
(Ursprungsgeschichte des Bewusstseins, 1949) Neumann repeatedly reminds us psycho-biological nature of the psyche and uses the same term "primordial image" (Urbild) as Jung and Carus before him. Thus both Neumann and Jung constitute more detailed elaboration of Carus' ideas:

\begin{abstract}
"The structural elements of the collective unconscious are named by Jung 'archetypes' or 'primordial images'. They are the pictorial forms of the instincts, for the unconscious reveals itself to the conscious mind in images (...). As organs of the psyche's structure the archetypes articulate with one another autonomously, like the physical organs, and determine the maturation of the personality in a manner analogous to the biological hormone-components of the physical constitution" (Neumann 2014, xv-xvi).
\end{abstract}

So-called "recapitulation principle", also anticipated by Carus, was one of leading principles of Jungian psychology and its various ramifications throughout the $20^{\text {th }}$ century. Neumann reminds it as one of the leading principles of his work:

\begin{abstract}
"Ego consciousness evolves passing through a series of 'eternal images', and the ego, transformed in the passage, is constantly experiencing a new relation to the archetypes. (...) The ability to perceive, to understand, and to interpret these images changes as ego consciousness changes in the course of man's phylogenetic and ontogenetic history; (...) The evolution of consciousness by stages is as much a collective human phenomenon as a particular individual phenomenon. Ontogenetic development may therefore be regarded as a modified recapitulation of phylogenetic development" (Neumann 2014, xvi, xx).
\end{abstract}

Even though the way we see the link between phylogenetic and ontogenetic level within human psyche has changed and is viewed from a bit different perspective and even though this aspect of Neumann's work was revisited and received a fundamental critique from Giegerich (Giegerich 1975) already in 1970s, historical and developmental nature of psyche as anticipated by Carus still makes part of different (and differing) Jungian and post-Jungian schools.

\title{
References
}

ADAMS, M. V. (2004a): Jungian Sost-Structural Theory. Structures Versus Constructs, Concepts Versus Images. In: ADAMS, M. V.: The Fantasy Principle. Psychoanalysis of the Imagination, New York: Brunner-Routledge, 40-56.

ADAMS, M. V. (2004b): The Fantasy Principle. Imaginal Psychology and the Dethroning and the Dethroning of 'Mr. Reality'. In: The Fantasy Principle. Psychoanalysis of the Imagination. New York: Brunner-Routledge, 1-19. 
BELL, M. (2010): Carl Gustav Carus and the Science of the Unconscious. In: Angus Nicholls, Martin Liebscher (eds.).: Thinking the Unconscious: Nineteenth-Century German Thought. Cambridge: Cambridge University Press, 156-172.

CARUS, C. G. (1989): Psyche: On the Development of the Soul. Dallas, Texas: Spring.

CARUS, C. G. (1846): Psyche: Zur Entwicklungsgeschichte der Seele. Pforzheim: Flammer und Hoffmann.

CARUS, C. G. (1831): Vorlesungen über Psychologie, gehalten in Winter 1829-30 zu Dresden. Leipzig: Verlag von Gerhard Fleisher.

DESCARTES, R. (1996): Meditations on First Philosophy. Cambridge: Cambridge University Press.

DOUGLAS, C. (2008): The Historical Context of Analytical Psychology. In: YoungEisendrath, P. - Dawson, T.: The Cambridge Companion to Jung. Cambridge: Cambridge University Press, 19-38.

ELLENBERGER, H. (1970): Discovery of the Unconscious. The History and Evolution of Dynamic Psychiatry. USA: BasicBooks.

GIEGERICH, W. (1975): Ontogeny = Phylogeny? A Fundamental Critique of Erich Neumann's Analytical Psychology. In: An Annual of Archetypal Psychology and Jungian Thought, 110-129.

GIEGERICH, W. (2012): What is Soul? New Orleans: Spring Journal Books.

GÖDDE, G. (2010): Freud and Nineteenth-Century Philosophical Sources on the Unconscious. In: Nicholls, A. - Liebscher, M. (eds.): Thinking the Unconscious: Nineteenth-century German Thought. Cambridge: Cambridge University Press, 261-286.

HAUKE, C. (2006): The Unconscious: Personal and Collective. In: Papadopulos, Renos K. (ed.): The Handbook of Jungian Psychology. Theory, Practice and Application. London: Routledge, 2006, 54-73.

HILLMAN, J. (1983): Inter Views. Conversations with Laura Pozzo on Psychotherapy, Biography, Love, Soul, Dreams, Work, Imagination, and the State of Culture. USA: Harper \& Row.

HILlMAN, J. (1997): The Myth of Analysis. Three Essays in Archetypal Psychology. Evanson, Illinois: Northwestern University Press.

JUNG, C. G. (1953-1991): CW: The Collected Works of C. G. Jung. (20 vols., eds. H. Read, M. Fordham, G. Adler, W. McGuire). Princeton, NJ: Princeton University Press, and London: Routledge.

KUGLER, P. (2008): Psychic Imagining: A Bridge Between Subject and Object, In: Young-Eisendrath, P. - Dawson, T: The Cambridge Companion to Jung. Cambridge: Cambridge University Press, 77-91.

LEIBNIZ, G. W. (1996): New Essays on Human Understanding (ed., trans. Peter Remnant and Jonathan Bennett). Cambridge: Cambridge University Press. LOCKE, J. (1997): An Essay Concerning Human Understanding. London: Penguin. 
NEUMANN, E. (1983): The Great Mother. An Analysis of the Archetype. Princeton, New Jersey: Princeton University Press.

NEUMANN, E. (2014): The Origins and History of Consciousness. New York: Princeton University Press.

NICHOLLS, A. - LIEBSCHER, M. (2010): Introduction: Thinking the Unconscious. In: Nicholls, A. - Liebscher, M.: Thinking the Unconscious. Nineteenth-Century German Thought. Cambridge: Cambridge University Press, 2010, 1-25.

REGEBOGEN, A. - BRANDES, H. (1990): Unbewußte, das. In: Sandkühler, H. J. (ed.): Europäische Enzyklopädie zu Philosophie und Wissenschaften, vol. IV. Hamburg: Felix Meiner, 647-661.

SHAMDASANI, S. (2010): Epilogue: The “Optional” Unconscious. In: Nicholls, A. Liebscher, M. (eds.): Thinking the Unconscious. Nineteenth-Century German Thought, Cambridge: Cambridge University Press, 287-296.

SINGER, T. (2012): Introduction. In: Amezaga, P. -Barcellos, G. - Capriles, Á. et al. (eds.): Listening to Latin America. Exploring Cultural Complexes in Brazil, Chile, Colombia, Mexico, Uruguay, and Venezuela. New Orleans: Spring Journal Books, 1-13.

STEIN, M. (1989): Appendix. Precis of Parts Two and Three of Psyche. In: Carus, C.

G.: Psyche. On the Development of the Soul. Dallas, Texas: Spring, 75-85.

STEIN, M. (2006): Individuation. In: Papadopulos, Renos, K. (ed.): The Handbook of Jungian Psychology. Theory, Practice and Application. 196-214.

WOLFF, C. (1983): Vernünfftige Gedancken von Gott, Gesammelte Werke. Ed. J. École et al., part 1, vol. 2, Hildesheim: Georg Olms.

\section{Aleš Vrbata, PhD.}

State University of Feira de Santana

Literature and Cultural Diversity Post-Graduate Department

AVENIDA TRANSNORDESTINA S/N

Caixa Postal: $252-294$

CEP: 44.036-900

Feira de Santana

Brasil

alesvrbata@hotmail.com 